\title{
Specific PCR Detection of Four Quarantine Fusarium Species in Korea
}

\author{
Sae-Yeon Hong', Mi Ran Kang ${ }^{1}$, Eun-Ji Cho ${ }^{1}$, Hee-Kyoung Kim ${ }^{1,2}$ and Sung-Hwan Yun ${ }^{1 *}$ \\ ${ }^{1}$ Department of Medical Biotechnology, and ${ }^{2}$ Research Institute for Basic Sciences, Soonchunhyang University, Asan 336-745, \\ Korea
}

(Received on November 4, 2010; Accepted on November 18, 2010)

\begin{abstract}
Fusarium species, a large group of plant pathogens, potentially pose quarantine concerns worldwide. Here, we focus on the development of a method for detecting four Fusarium species in quarantined plants in Korea: $F$. solani f. sp. cucurbitae, F. stilboides, F. redolens, and $F$. semitectum var. majus. Species-specific primers were designed from the nucleotide sequences of either the translation elongation factor-1 alpha (TEF1) gene or RNA polymerase II subunit (RPB2) gene. Two different primer sets derived from $T E F 1$, all specific to $F$. solani $f$. sp. cucurbitae, were able to differentiate the two races (1 and 2) of this species. A set of nested primers for each race was designed to confirm the PCR results. Similarly, two primer sets derived from $R P B 2$ successfully amplified specific fragments from five $F$. stilboides isolates grouped within a single phylogenetic clade. A specific $T E F 1$ primer set amplified a DNA fragment from only four of the $12 F$. redolens strains examined, which were grouped within a single phylogenetic clade. All of the $F$. semitectum var. majus isolates could be specifically detected with a single $R P B 2$ primer set. The specificity of the primer sets developed here was confirmed using a total of 130 Fusarium isolates.
\end{abstract}

Keywords: Fusarium, PCR detection, quarantine fungi, specific primers

Fusarium is a large genus of filamentous fungi that includes a broad range of plant pathogens causing wilt and crown and root rot in a variety of hosts. Some members of this genus also produce various toxic secondary metabolites such as mycotoxins, which are harmful to both human and plant health. Due to the diversity of plant diseases caused by Fusarium species, these species potentially pose quarantine concerns worldwide. In Korea, eleven pathogenic Fusarium species are listed as quarantine pests ( $F$. solani $\mathrm{f}$. sp. cucurbitae, F. stilboides, F. semitectum var. majus, $F$. oxysporum var. redolens, $F$. oxysporum f. sp. cattleyae, $F$. oxysporum f. sp. citri, $F$. oxysporum f. sp. cubense, $F$.

\footnotetext{
*Corresponding author.

Phone) +82-41-530-1288, FAX) +82-41-530-3085

E-mail)sy14@sch.ac.kr
}

oxysporum f. sp. radicis-lycopersici, F. culmorum, F. poae, and $F$. sulphureum). Here, we report a PCR detection method developed specifically for the first four Fusarium species.

Fusarium solani f. sp. cucurbitae causes Fusarium crown, fruit, and root rot in cucurbits. This species can be divided into two different races (1 and 2): race 1 (telomorph: Nectria haematococca mating population I) causes crown, fruit, and root rot, whereas race 2 (telomorph: $N$. haematococca mating population V) affects only the fruit. Currently, the races are thought to be distinct species, as they are clearly different in terms of sexual mating behavior, other taxonomic characters, and DNA sequence homology (Mehl and Epstein, 2007). F. stilboides causes bark and fruit rot of citrus and coffee (Gerlach and Nirenberg, 1982), and is a member of the Lateritium clade of Fusarium; it is still difficult to distinguish it from some isolates of $F$. lateritium, which also belongs to the Lateritium clade (Geiser et al., 2005). F. semitectum var. majus, a cosmopolitan species, is one of the two varieties of $F$. semitectum (the other is var. semitectum) and is regularly associated with a complex of plant diseases (Hawa et al., 2010). F. redolens causes wilt, seedling damping-off, and cortical rot and used to be recognized at either the variety or forma specialis level of $F$. oxysporum (F. oxysporum var. redolens or F. oxysporum $\mathrm{f}$. sp. redolens), but is now known to be distinct from $F$. oxysporum (Bogale et al., 2007). In Korea, the detection of these pathogenic Fusarium species in quarantine services relies mostly on the morphology of conidia produced on plant samples, which not only delays the quarantine procedures, but also lead to misidentification of the fungal species. Therefore, it is necessary to develop a fast, reliable method that specifically detects these quarantine species.

The objectives of this study were to 1) confirm the species identification of the Fusarium isolates collected for this study using a phylogenetic analysis, 2) design speciesspecific PCR primer sets for the four quarantine Fusarium species, and 3) determine their specificity, sensitivity, and reliability.

Collection of Fusarium isolates. For this study, 130 Fusarium isolates were collected from several culture col- 
Table 1. Fusarium species used in PCR analysis

\begin{tabular}{|c|c|c|}
\hline Isolate & Species & Source \\
\hline K40031 & F. oxysporum f. sp. radicis-lycopersici race 3 & \\
\hline K40032 & F. oxysporum f. sp. lycopersici race 3 & \\
\hline K40037 & F. oxysporum f. sp. lycopersici race 2 & \\
\hline K40038 & F. oxysporum f. sp. lycopersici race 2 & \\
\hline K40046 & F. oxysporum f. sp. lycopersici race 1 & \\
\hline K40047 & F. oxysporum f. sp. lycopersici race 1 & \\
\hline K40052 & F. oxysporum & \\
\hline K40053 & F. oxysporum & \\
\hline K41081 & F. oxysporum & \\
\hline K41083 & F. oxysporum & \\
\hline K41087 & F. oxysporum & \\
\hline K41088 & F. oxysporum & \\
\hline K41090 & F. oxysporum & \\
\hline K40236 & F. oxysporum & \\
\hline K44305 & F. oxysporum & \\
\hline K41036 & F. semitectum & \\
\hline K40384 & F. solani & \\
\hline K41092 & F. solani & \\
\hline K41093 & F. solani & \\
\hline K44803 & F. acuminatum & \\
\hline K44819 & F. acutatum & \\
\hline K44820 & F. avenaceum & \\
\hline K42160 & F. cerealis & \\
\hline K42159 & F. cerealis & \\
\hline K44946 & F. circinatum & KACC \\
\hline K44570 & F. circinatum & \\
\hline K44569 & F. circinatum & \\
\hline K42162 & F. culmorum & \\
\hline K42161 & F. culmorum & \\
\hline K41312 & F. culmorum & \\
\hline K44021 & F. fujikuroi & \\
\hline K44019 & F. fujikuroi & \\
\hline K44017 & F. fujikuroi & \\
\hline K44015 & F. fujikuroi & \\
\hline K44010 & F. fujikuroi & \\
\hline K44009 & F. fujikuroi & \\
\hline K44004 & F. fujikuroi & \\
\hline K42687 & F. fujikuroi & \\
\hline K42686 & F. fujikuroi & \\
\hline K42702 & F. globosum & \\
\hline K42701 & F. globosum & \\
\hline K41034 & F. lateritium & \\
\hline K42689 & F. nygamai & \\
\hline K42688 & F. nygamai & \\
\hline K42271 & F. oxysporum f. sp. asparagi & \\
\hline K42273 & F.oxysporum f. sp. chrysanthemi & \\
\hline K42274 & F. oxysporum f. sp. ciceris & \\
\hline K42276 & F. oxysporum f. sp. conglutinans & \\
\hline K42275 & F. oxysporum f. sp. glycines & \\
\hline
\end{tabular}

Table 1. Continued

\begin{tabular}{|c|c|c|}
\hline Isolate & Species & Source \\
\hline K42795 & F. oxysporum f. sp. lactucae & \multirow{23}{*}{$\mathrm{KACC}$} \\
\hline K42272 & F. oxysporum f. sp. cassiae & \\
\hline K42169 & F. oxysporum f.sp. fragariae & \\
\hline K42172 & F. oxysporum f.sp. pisi & \\
\hline K42173 & F. oxysporum f.sp. sesami & \\
\hline K44025 & F. proliferatum & \\
\hline K44024 & F. proliferatum & \\
\hline K42694 & F. proliferatum & \\
\hline K42693 & F. proliferatum & \\
\hline K42692 & F. proliferatum & \\
\hline K44846 & F. pseudograminearum & \\
\hline K42695 & F. sacchari & \\
\hline K41317 & F. sambucinum var. sambucinum & \\
\hline K43387 & F. solani & \\
\hline K42177 & F. solani f.sp. batatas & \\
\hline K42178 & F. solani f.sp. mori & \\
\hline K42181 & F. solani f.sp.pisi & \\
\hline K42182 & F. solani f.sp. robiniae & \\
\hline K42696 & F. subglutinans & \\
\hline K42852 & F. verticillioides & \\
\hline K42699 & F. verticillioides & \\
\hline K42698 & F. verticillioides & \\
\hline K41321 & F. verticillioides & \\
\hline Z03639 & F. graminearum & \multirow{15}{*}{$\begin{array}{l}\text { Dr. J. Leslie, } \\
\text { Kansas State } \\
\text { Univ., USA }\end{array}$} \\
\hline Z03643 & F. graminearum & \\
\hline H48661 & F. pseudograminearum & \\
\hline H11553 & F. sporotrichioides & \\
\hline H11568 & F. chlamydosporum & \\
\hline SNU-lyco & F. oxysporum f. sp. lycopersici & \\
\hline GS2-2 & F. semitectum & \\
\hline GS2-18 & F. semitectum & \\
\hline F16 & F. asiaticum (13818) & \\
\hline F20 & F. boothii (26916) & \\
\hline F24 & F. mesoamericanum (25797) & \\
\hline F30 & F. brasilicum $(31281)$ & \\
\hline F34 & F. meridionale (28723) & \\
\hline F37 & F. lunlosporum (13393) & \\
\hline F39 & F. culmorum (3288) & \\
\hline C145.44 & F. semitectum var. majus & \multirow{9}{*}{ CBS } \\
\hline C161.25 & F. semitectum var. majus & \\
\hline C163.57 & F. semitectum var. majus & \\
\hline C319.73 & F. stilboides & \\
\hline C746.79 & F. stilboides & \\
\hline C101890 & F. stilboides & \\
\hline C101891 & F. stilboides & \\
\hline C101892 & F. stilboides & \\
\hline C115624 & F. stilboides & \\
\hline $\mathrm{O} 0225$ & F. oxysporum f. sp. cubense & \multirow{2}{*}{ FRC } \\
\hline O1223 & F. oxysporum f. sp. cubense race 1 & \\
\hline
\end{tabular}


Table 1. Continued

\begin{tabular}{|c|c|c|}
\hline Isolate & Species & Source \\
\hline $\mathrm{O} 1564$ & F. oxysporum f. sp. cubense race 1 & \multirow{32}{*}{ FRC } \\
\hline O1565 & F. oxysporum f. sp. cubense race 1 & \\
\hline O1566 & F. oxysporum f. sp. cubense race 1 & \\
\hline O1567 & F. oxysporum f. sp. cubense race 2 & \\
\hline O1568 & F. oxysporum f. sp. cubense race 4 & \\
\hline O1955 & F. oxysporum f. sp. cubense & \\
\hline O1968 & F. oxysporum f. sp. cubense & \\
\hline O1090 & F. oxysporum f. sp. radicis-lycopersici & \\
\hline O1092 & F. oxysporum f. sp. radicis-lycopersici & \\
\hline O1097 & F. oxysporum f. sp. radicis-lycopersici & \\
\hline O1101 & F. oxysporum f. sp. radicis-lycopersici & \\
\hline O1102 & F. oxysporum f. sp. radicis-lycopersici & \\
\hline O1973 & F. oxysporum f. sp. radicis-lycopersici & \\
\hline $\mathrm{O} 2022$ & F. oxysporum f. sp. radicis-lycopersici & \\
\hline $\mathrm{O} 2023$ & F. oxysporum f. sp. radicis-lycopersici & \\
\hline $\mathrm{O} 1140$ & F. oxysporum var. redolens (F. redolens) & \\
\hline O1265 & F. oxysporum var. redolens & \\
\hline O1266 & F. oxysporum var. redolens & \\
\hline O1320 & F. oxysporum var. redolens & \\
\hline O1380 & F. oxysporum var. redolens & \\
\hline $\mathrm{O} 1523$ & F. oxysporum var. redolens & \\
\hline O1792 & F. oxysporum var. redolens & \\
\hline O1793 & F. oxysporum var. redolens & \\
\hline O1891 & F. oxysporum var. redolens & \\
\hline O1893 & F. oxysporum var. redolens & \\
\hline O1926 & F. oxysporum var. redolens & \\
\hline S0201 & F. solani f. sp. cucurbitae race 2 & \\
\hline S0202 & F. solani f. sp. cucurbitae race 2 & \\
\hline S0203 & F. solani f. sp. cucurbitae race 2 & \\
\hline S0687 & F. solani f. sp. cucurbitae race 1 & \\
\hline S0688 & F. solani f. sp. cucurbitae race 1 & \\
\hline S0696 & F. solani f. sp. cucurbitae race 1 & \\
\hline
\end{tabular}

KACC: Korean Agricultural Culture Collection, Suwon, Korea. CBS: the Centraalbureau voor Schimmelcultures, Utrecht, Netherlands. FRC: Fusarium Research Center, University Park, PA, USA.

lections (Table 1). Of these, 44 Fusarium isolates of six species $[F$. oxysporum f. sp. cubense, $F$. oxysporum f. sp. radicis-lycopersici, F. redolens (F. oxysporum var. redolens), $F$. solani f. sp. cucurbitae, $F$. semitectum var. majus, and $F$. stilboides] are listed as quarantine fungi in Korea. The remaining isolates were closely or distantly related species within the genus Fusarium. All isolates were stored in 25\% glycerol at $-80^{\circ} \mathrm{C}$ and maintained on potato dextrose agar (PDA; Difco Laboratories, Detroit, MI, USA). For genomic DNA extraction, they were grown in $50 \mathrm{ml}$ of PD broth at $25^{\circ} \mathrm{C}$ for 3 days with shaking (150 rpm). Fungal genomic DNA was extracted as described previously (Chi et al., 2009).
Table 2. The nucleotide sequences of $T E F 1$ from the reference Fusarium strains used in the phylogenetic analysis

\begin{tabular}{|c|c|c|}
\hline Strain & Species & Accession $\#^{\mathrm{a}}$ \\
\hline NRRL25600 & F. redolens & AF324294 \\
\hline NRRL26762 & F. redolens & AF324313 \\
\hline NRRL28425 & F. redolens & AF324308 \\
\hline NRRL28909 & F. redolens & AF324318 \\
\hline NRRL 52645 & F. redolens & GU250583 \\
\hline $40 / 2.5$ & F. redolens & DQ854918 \\
\hline $60 / 2.1 .1$ & F. redolens & DQ854922 \\
\hline 43412 & F. solani f. sp. cucurbitae race 1 & DQ986186 \\
\hline 43413 & F. solani f. sp. cucurbitae race 1 & DQ986187 \\
\hline 43417 & F. solani f. sp. cucurbitae race 1 & DQ986191 \\
\hline 43419 & F. solani f. sp. cucurbitae race 1 & DQ986193 \\
\hline 43423 & F. solani f. sp. cucurbitae race 1 & DQ986196 \\
\hline 43424 & F. solani f. sp. cucurbitae race 1 & DQ986197 \\
\hline 43425 & F. solani f. sp. cucurbitae race 1 & DQ986198 \\
\hline HLM133 & F. solani f. sp. cucurbitae race 2 & DQ913751 \\
\hline HLM203 & F. solani f. sp. cucurbitae race 2 & DQ913755 \\
\hline HLM258 & F. solani f. sp. cucurbitae race 2 & DQ913761 \\
\hline HLM217 & F. solani f. sp. cucurbitae race 2 & DQ913756 \\
\hline HLM255 & F. solani f. sp. cucurbitae race 2 & DQ913758 \\
\hline HLM256 & F. solani f. sp. cucurbitae race 2 & DQ913759 \\
\hline NRRL22142 & F. solani f. sp. cucurbitae race 2 & AF178347 \\
\hline IBT24 & F. stilboides & EF526102 \\
\hline IBT7 & F. stilboides & EF526101 \\
\hline ISPaVe 1946 & F. incarnatum $(=F$. semitectum $)$ & FN430737 \\
\hline NRRL 31160 & F. incarnatum $(=F$. semitectum $)$ & GQ915510 \\
\hline $1559 \mathrm{~A}$ & F. incarnatum $(=F$. semitectum $)$ & FJ895279 \\
\hline
\end{tabular}

${ }^{\mathrm{a}}$ GenBank accession numbers

Phylogenetic analysis. To confirm both the species identification of the collected Fusarium isolates and their phylogenetic relationships, partial nucleotide sequences of genes frequently used as DNA markers [those for translation elongation factor 1-alpha (TEF1), RNA polymerase second largest subunit (RPB2), beta-tubulin (TUB1), and calmodulin M (calM)] were amplified from 77 of the collected 130 isolates. In addition, we attempted to amplify a partial fragment of pheromone precursor gene $(P P G l)$ from these isolates using a $P P G 1$-specific primer set (Kim et al., 2008). The TEF1 sequences of several Fusarium species deposited in the National Center for Biotechnology Information (NCBI; http://www.ncbi.nlm.nih.gov) (Table 2) were used as reference sequences for a phylogenetic analysis. All primers (Table 3) used for PCR amplification were synthesized by Bioneer Corporation (Daejeon, Korea). Each reaction tube contained $50 \mathrm{ng}$ of template DNA, $1 \times$ PCR buffer, dNTPs at $0.2 \mathrm{mM}$ each, primers at 10 $\mu \mathrm{M}$, and 1.25 U ExTaq polymerase (Takara Biomedicals, Shiga, Japan) in $50-\mu 1$ reaction volumes. The PCR reactions 
Table 3. Primers used to amplify DNA markers

\begin{tabular}{llc}
\hline \hline Primer & \multicolumn{1}{c}{ Sequence $\left(5^{\prime} \rightarrow 3^{\prime}\right)$} & Amplified genes \\
\hline EF-1 & ATGGGTAAGGA(A/G)GACAAGAC & TEF1 (O'Donnell et al., 1998) \\
EF-2 & GGA(G/A)GTACCAGT(G/C)ATCATGTT & TUB1 (O'Donnell \& Cigelnik, 1997) \\
tubT1 & AACATGCGTGAGATTGTAAGT & \\
tubT22 & TCTGGATGTTGTTGGAATCC & RPB2 (Liu et al., 1999) \\
fRPB2-cF & ATGGG(C/T)AA(A/G)CAAGC(C/T)ATGGG & \\
fRPB2-11aR & GC(A/G)TGGATCTT(A/G)TC(A/G)TC(C/G)ACC & calM (Mulè et al., 2004) \\
CLOX1 & CAGCAAAGCATCAGACCACTATAACTC & \\
CLOX2 & CTTGTCAGTAACTGGACGTTGGTACT & \\
\hline
\end{tabular}

were performed with an initial denaturation at $94^{\circ} \mathrm{C}$ for 2 min, 30 cycles of $94^{\circ} \mathrm{C}(1 \mathrm{~min}) / 50^{\circ} \mathrm{C}$ or $55^{\circ} \mathrm{C}(1 \mathrm{~min}) / 72^{\circ} \mathrm{C}$ ( $2 \mathrm{~min}$ ), and a final extension at $72^{\circ} \mathrm{C}$ for $10 \mathrm{~min}$. A 710-bp TEF1 and $\sim 970-b p$ RPB2 fragment were successfully amplified from all 77 isolates examined, whereas the $\sim 530$-bp calM product was not isolated from six of the 77 isolates. However, a 710-bp PPG1 fragment was amplified from only a few isolates, so the attempt to use PPG1 as a new DNA marker was not successful in this study. All of the amplified products were cloned into pGEMT vector (Promega, Madison, WI, USA), and their nucleotide sequences were determined using primers T7 and SP6 then extended, when needed, using a primer corresponding to the previously determined regions (for $T U B 1$ ). All the nucleotide sequences for each isolate were deposited in the Plant Pathogen DNA Bank (PPDA; http://ppda.riceblast.snu.ac.kr) and are available on request. Sequences were edited with Lasergene v6.0 (DNASTAR, Madison, WI, USA) and aligned using ClustalW (Thompson et al., 1994). Maximum parsimony (MP) analyses were performed using MEGA ver. 4.02 (Tamura et al., 2007). The robustness of the MP trees (MPTs) was determined using the full heuristic search option for 1,000 bootstrap replications. The TEF1 dataset comprised 99 taxa, including 26 from sequence databases with 786 characters, of which 384 were constant, and 317 were parsimony-informative and 402 parsimony-uninformative, generating 481 MPTs. The RPB2 analysis yielded 267 MPTs from a dataset comprising 986 characters, including 684 uninformative positions and 302 parsimonyinformative positions. The TEF1 and RPB2 trees had similar topographies that revealed seven strongly supported clades [more than $90 \%$ bootstrap support (BS)], each corresponding to the taxonomic positions of most of the collected Fusarium isolates (Fig. 1); the topology of the calM tree was different from those of the other genes (data not shown). Five of the six $F$. stilboides isolates examined were grouped within a single clade ( $99 \% \mathrm{BS})$, whereas the remaining one (C115624) belonged to the F. oxysporum complex clade, suggesting that the species identification of $\mathrm{C} 115624$ is incorrect. The three F. semitectum var. majus isolates ex- amined were placed in a single clade (99\% BS) along with the isolates of the closely related species $F$. semitectum; it is still unclear whether the two F. semitectum isolates (GS2-2 and GS2-18) examined and other $F$. semitectum reference strains available in NCBI are distinct from $F$. semitectum var. majus. The F. solani f. sp. cucurbitae race 1 (S0687, S0688, and S0696) and race 2 (S0201, S0202, and S0203) isolates examined here formed two separate clades $(99 \%$ BS), each along with reference strains, implying that the two races of $F$. solani f. sp. cucurbitae are phylogenetically distinct species (Mehl and Epstein, 2007). In addition, the other F. solani isolates (K40384, K41092, and K41093), whose forma speciales levels have not been identified, grouped within a different subclade, indicating that they are phylogenetically distinct from the $F$. solani f. sp. cucurbitae isolates. In contrast to the Fusarium species described above, most isolates of the F. oxysporum complex resided in a single clade (97\% BS), but their forma speciales (e.g., cubense, lycopersici, radicis-lycopersici, and lycocersici) were not resolved further into strongly supported subclades. This supports the hypothesis that $F$. oxysporum is a complex of morphologically similar fungi, but its forma speciales are not separated as reliable taxonomic categories (Baayen et al., 2000; O’Donnell et al., 1998). However, four (O1265, O1266, O1891, and O1893) of the eleven $F$. redolens (synonym: F. oxysporum var. redolens) examined here resided within a distinct clade, implying that these two taxa are different species (Bogale et al., 2007), although morphology-based diagnoses of $F$. redolens and $F$. oxysporum are still challenging. In this respect, the $F$. redolensspecific clade suggests that the other seven $F$. redolens isolates await further confirmation for species identification.

PCR amplification using species-specific primer sets. We attempted to design specific primer sets for fungal isolates belonging to four quarantine species ( $F$. solani $\mathrm{f}$. sp. cucurbitae, F. stilboides, F. semitectum var. majus, and $F$. redolens), each of which resided within a strongly supported clade in the phylogenetic tree (Fig. 1). Based on the 


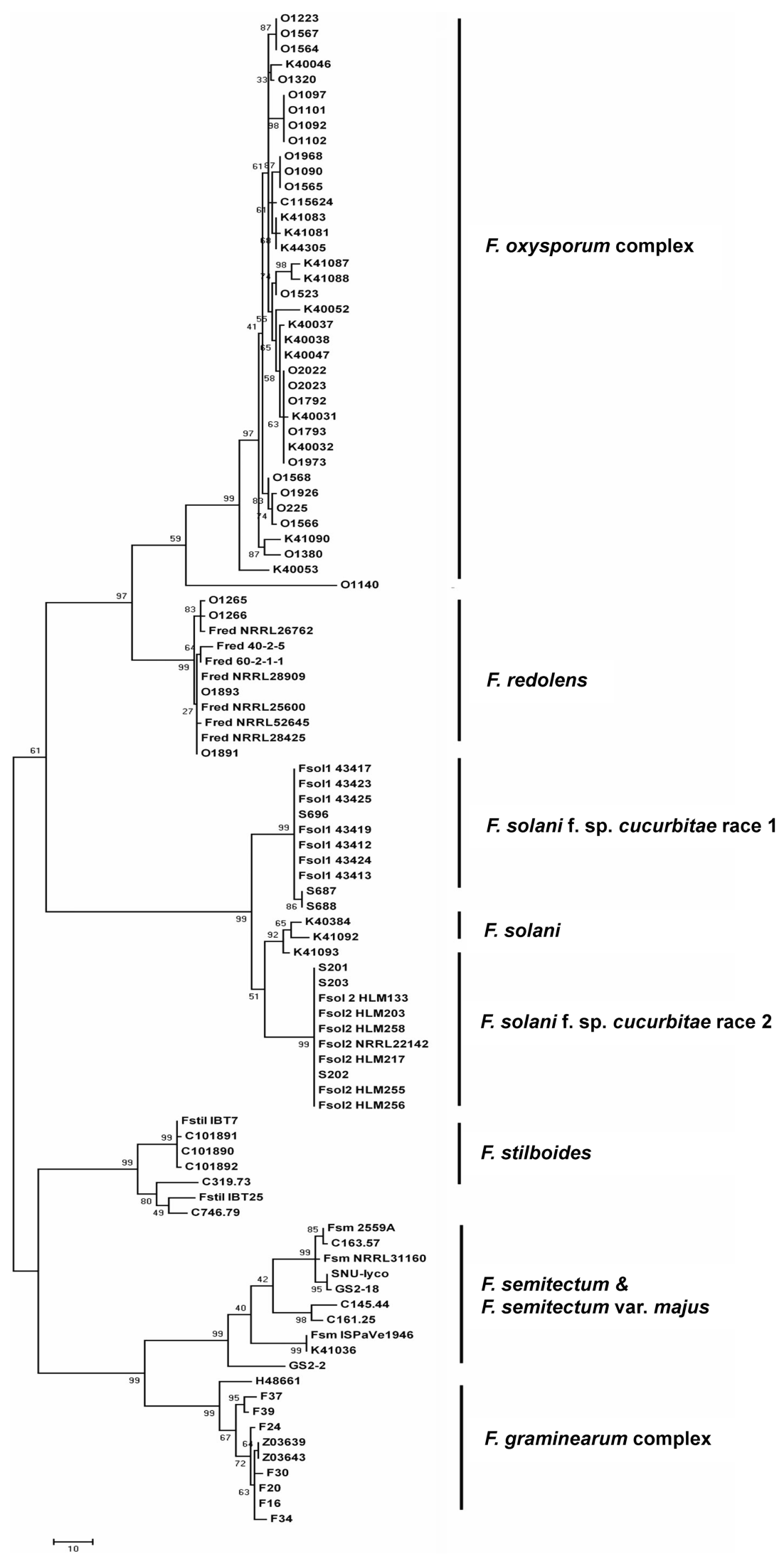

Fig. 1. A phylogenetic tree constructed from the TEF1 genes of the collected Fusarium species using the maximum parsimony (MP) method. The numbers at the nodes indicate bootstrap values estimated from 1,000 replications of the dataset. 
Table 4. Specific primers designed in this study

\begin{tabular}{|c|c|c|}
\hline Primer & Sequence $\left(5^{\prime} \rightarrow 3^{\prime}\right)$ & primer specificity \\
\hline Fsc1 & CGTGATTGGGACGGATGAGAGA & forward primer for $F$. solani f. sp. cucurbitae $(F s c)$ race 1 \\
\hline Fsc2 & ACGTGAGTGAGAGACATGACGG & forward primer for $F s c$ race 2 \\
\hline Tsolre1FM & ACATACCAATGACGGTGACATAGTA & forward primer for $F s c$ races $1 \& 2$, and $F$. redolens \\
\hline Fsolc1R1 & TGGCATCTTGGGCGGGGGGT & reverse primer for $F s c$ race 1 \\
\hline Fsolc2R1 & TTCACAACAGACACTGACTCG & reverse primer for $F s c$ race 2 \\
\hline TsollR & CTGCTTATCTTGGGTCGTGG & reverse primer for $F S c$ races $1 \& 2$, and other $F$. solani isolates \\
\hline TredolR & TTCGACTCGCCGCTCCCA & reverse primer for F. redolens \\
\hline SmibolFM & GCAAAAGCCTCTCGCCAC & forward primer for both $F$. stilboides and $F$. semitectum \\
\hline FstR1 & GACACCAATAGTACCCTTTTGTC & reverse primer for $F$. stilboides \\
\hline StibolRM & GTGCTTCATTCGGAGAGTTTG & reverse primer for $F$. stilboides \\
\hline SemilRM & AGGTGTAGAGATATCGCGG & reverse primer for $F$. semitectum \\
\hline
\end{tabular}

aligned TEF1 or RPB2 nucleotide sequences, we searched variable regions for each species in generating the primer sets (Table 4). Using the TEF1 sequences, two different primer sets were designed for the PCR detection of $F$. solani f. sp. cucurbitae race 1. The primer pairs Fsc1Tsol1R and Tsolre1FM-Fsolc1R1 (Table 4) amplified 580and 526-bp fragments, respectively, from genomic DNA of the three race 1 isolates of $F$. solani f. sp. cucurbitae; none of the race 2 isolates or the other Fusarium isolates including $F$. solani generated the specific amplified fragments (Fig. 2A). In addition, the second primer pair (Tsolre1FM and Fsolc1R1) can be used as a nested primer set using a 100-fold diluted PCR product amplified by the first primer pair as template DNA; no specific amplification was observed from the first PCR products of the isolates of race 2 and other Fusarium spp. (Fig. 2A). Similarly, two primer pairs (Fsc2-Tsol1R and Tsolre1FM-Fsolc2R1) were designed for the specific amplification of F. solani f. sp. cucurbitae race 2 . These primer sets successfully amplified 580- and 174-bp fragments, respectively, from genomic DNA of the race 2 isolates, but not from other fungal isolates, including race 1 and $F$. solani; as in the case of the race 1 isolates, the second primer set can be used as a nested primer set (Fig. 2B). These results support the classification of the two races of $F$. solani f. sp. cucurbitae as distinct species (Mehl and Epstein, 2007). PCR with the primer pair Tsolre1FM and Tredo1R amplified a 343-bp fragment from only the four F. redolens isolates that reside within a single phylogenetic clade (Fig. 3A). Because the nucleotide sequence of the forward primer (Tsolre1FM) used in this PCR was completely conserved in all of the isolates of $F$. solani f. sp. cucurbitae and F. solani examined, a PCR fragment specific to each of these isolates could be amplified when using primer Tsol1R, which is specific to both $F$. solani f. sp. cucurbitae and $F$. solani, along with this primer. Therefore, multiplex PCR using the three primers (Tsolre1FM, Tsol1R, and Tredo1R) was attempted, and it amplified a specific fragment from either of these two

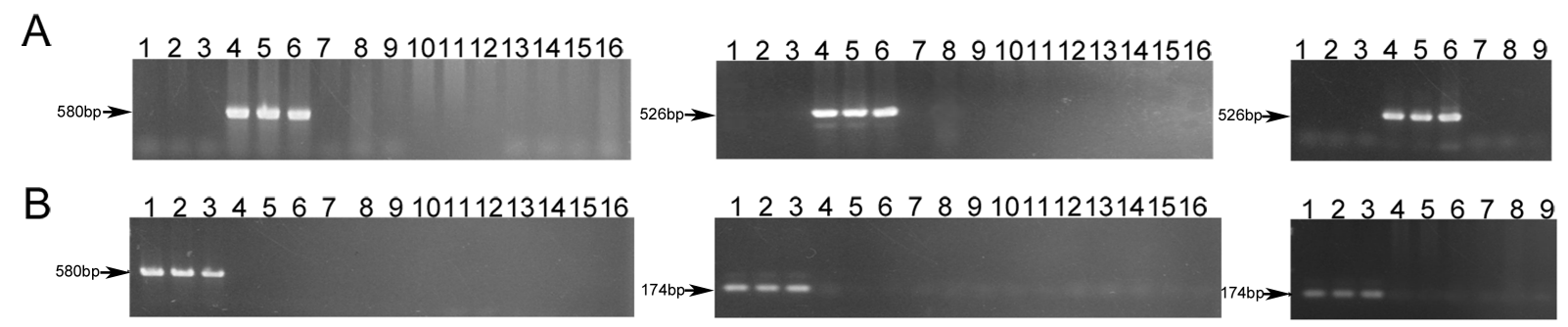

Fig. 2. Specific amplification of the TEF1 region from the isolates of $F$. solani $\mathrm{f}$. sp. cucurbitae $(F s c)$ race 1 (A) and race 2 (B). (A) Left panel: PCR amplification of a 580-bp fragment from genomic DNA of the Fsc race 1 isolates with the primers Fsc1 and TsollR. Lanes 13: the Fsc race 2 isolates (S201, S202, and S203, respectively); 4-6: the Fsc race 1 isolates (S687, S688, and S696, respectively); 7-9: the F. solani isolates (K40384, K41092, and K41093, respectively); 10-16: other Fusarium spp. Middle panel: PCR amplification of a 526bp fragment from genomic DNA of the Fsc race 1 isolates with the primers Tsolre1FM and Fsolc1R1. The lane descriptions are the same as those for the left panel. Right panel: PCR amplification of the 526-bp fragment from the 100-fold-diluted PCR products in the left panel as template DNA with Tsolre1FM and Fsolc1R1. The lane descriptions are the same as those for the left panel. (B) Left: PCR amplification of a 580-bp fragment from genomic DNA of the Fsc race 2 isolates with the primers Fsc2 and TsollR. Middle: PCR amplification of a 174-bp fragment from genomic DNA of the Fsc race 2 isolates with the primers Tsolre1FM and Fsolc2R1. Right: PCR amplification of the 174-bp fragment from the 100-fold diluted PCR products in the left panel as template DNA with Tsolre1FM and Fsolc2R1. The lane descriptions for the three panels are the same as those in (A). 

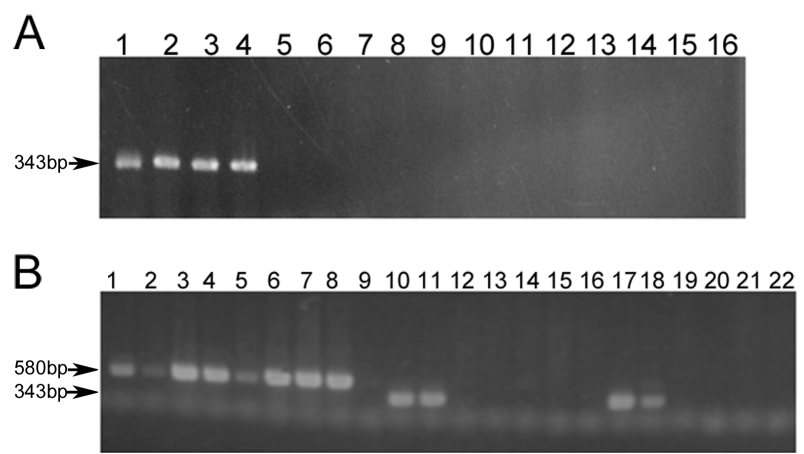

Fig. 3. Specific amplification of the TEF1 regions from genomic DNA of the F. redolens isolates using the primers Tsolre1FM and Tredo1R (A) and from those of the F. redolens and Fsc isolates using the three primers Tsolre1FM, TredolR, and TsollR (B). (A) Lanes 1-4: the F. redolens isolates (O1265, O1266, O1891, and O1893, respectively); 5-9: other F. redolens isolates (O1140, O1265, O1320, O1523, and O1793, respectively); 10-16: other Fusarium spp. (B) Lanes 1-2: the F. solani isolates (K40384, and K41092, respectively); 3-5: Fsc race 2 isolates (S201, S202, and S203, respectively); 6-8: the Fsc race 1 isolates (S687, S688, and S696, respectively); 10, 11, 17, 18: the $F$. redolens isolates (O1265, O1266, O1891, and O1893, respectively); 12-16: other F. redolens isolates (O1140, O1265, O1320, O1523, and $\mathrm{O} 1793$, respectively); 19-22: other Fusarium spp.

Fusarium species ( $F$. redolens and at least some of the $F$. solani complex) (Fig. 3B). This confirms that these three primers can be used not only to detect both quarantine Fusarium species simultaneously, but also to differentiate the two species based on size differences of the PCR products, which is more reliable than PCR detection based on the presence/absence of a specific PCR product. If the multiplex PCR shows positive results, F. solani f. sp. cucurbitae can be identified further at the race level with the specific primer sets described above (Tsolre1FMFsolc1R1 for race 1 and Tsolre1FM-Fsolc2R1 for race 2); no further PCR is necessary for F. redolens.

Using the RPB2 sequences, three primers were designed for the simultaneous PCR detection of both F. stilboides and F. semitectum var. majus (Table 4). One primer (Smibo1FM) was a common forward primer for both species, whereas two reverser primers (Fst1 and Semi1RM) were specific for $F$. stilboides and F. semitectum var. majus, respectively. These primer sets successfully amplified 578and 424-bp fragments from the genomic DNA of the isolates of $F$. stilboides and all of the F. semitectum var. majus, respectively (Fig. 4). The absence of the specific fragment found in F. stilboides C115624, which was identified as a member of the $F$. oxysporum complex clade instead of the F. stilboides clade in this study (Fig. 1), supports the species confirmation for five of the six $F$. stilboides isolates in the phylogenetic analysis. The only exception was that a DNA fragment was amplified from
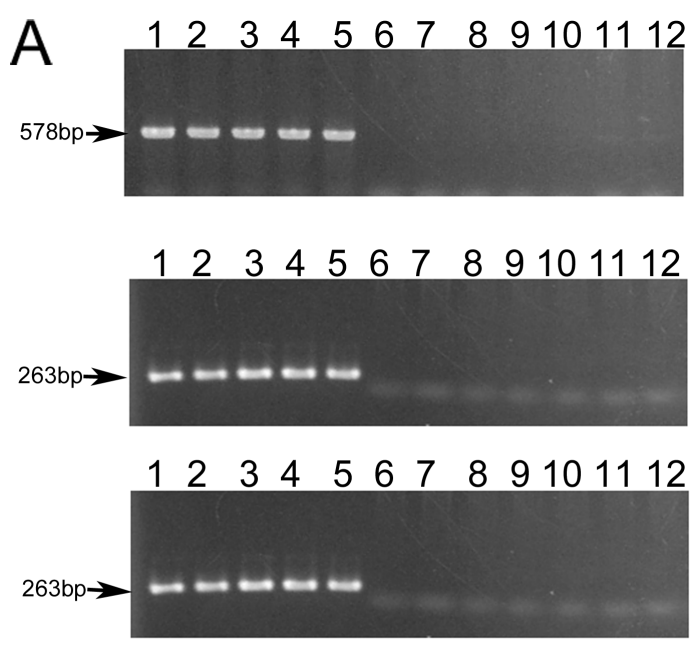

B

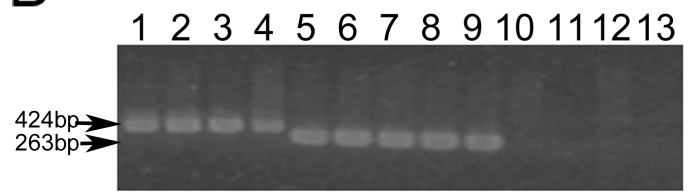

Fig. 4. Specific amplification of TEF1 regions from the isolates of $F$. stilboides and $F$. semitectum. (A) Upper panel: PCR amplification of a 578-bp fragment from genomic DNA of the $F$. stilboides isolates with the primers Smibo1FM and FstR1. Lanes 1-6: the F. stilboides isolates (C319.73, C746.79, C101890, C101891, C101892, and C115624, respectively); 7-16: other Fusarium spp. Middle panel: PCR amplification of a 263-bp fragment from genomic DNA of the F. stilboides isolates with the primers SmibolFM and StibolRM. Bottom panel: PCR amplification of the 263-bp fragment from the 100-fold-diluted PCR products in the upper panel as template DNA with SmibolFM and StibolRM. The lane descriptions for the middle and bottom panels are the same as those for the upper panel. (B) PCR amplification of the 263-bp fragment and a 424-bp fragment from $F$. stilboides and $F$. semitectum var. majus, respectively with the three primers Smibo1FM, SemilRM, and Stibo1RM. Lane 1: F. semitectum K41036; 2-4: the F. semitectum var. majus isolates (C145.44, C161.25, and C163.57, respectively); 5-10: the F. stilboides isolates (C319.73, C746.79, C101890, C101891, C101892, and C115624, respectively); 11-16: other Fusarium spp.

one F. lateritium isolate (data not shown), implying that this isolate is a member of the $F$. lateritium clade, some of which had previously been identified as $F$. stilboides (Geiser et al., 2005). To increase the reliability of the specific PCR detection developed for $F$. stilboides, a nested primer (Stilbo1RM) was used along with Smibo1FM to amplify a 263-bp fragment using the 100-fold-diluted PCR product (578 bp) amplified by the primer pair Smibo1FM and as a template (Fig. 4A). Multiplex PCR using the three primers (Smibo1FM, Semi1RM and Stibo1RM) in a single tube also amplified the expected PCR fragments from each species (Fig. 4B). By contrast, the specific PCR primers for $F$. semitectum var. majus also amplified the same-size 
fragment from some isolates of $F$. semitectum, indicating either that the primer specificity is not sufficient for $F$. semitectum var. majus, or that the F. semitectum isolates used here need further species confirmation at the infraspecific level. The detection limit for these assays was between 1 and 10 pg fungal genomic DNA per PCR reaction. The specificity of the primer sets developed here was confirmed using a total of 130 Fusarium isolates. In addition, the specific primers amplified no fragments from several fungal isolates other than the genus Fusarium, which were frequently contaminated in plant samples (data not shown).

To date, primer sets have been designed for the PCR detection of $F$. redolens and each of the $F$. solani $\mathrm{f}$. sp. cucurbitae races (Bogale et al., 2007; Mehl and Epstein, 2007), whereas no PCR primers have been developed for $F$. stilboides or F. semitectum var. majus. All of these previously developed primer sets also specifically amplified isolates of the corresponding Fusarium species. Based on the specificity and reliability of the primer sets developed here, they could be used in the PCR detection of the four different quarantine Fusarium species in imported plant samples. However, further analyses to increase the specificity and reliability of the PCR primer sets should be done in the near future. Especially, more field isolates of these quarantine Fusarium species (e.g., other forma speciales of $F$. solani and F. semitectum varieties) and closely related isolates must be tested. In addition, it is necessary to determine if the PCR reactions with the genomic DNA of various plant samples are able to amplify the specific PCR products efficiently when they are contaminated with the quarantine Fusarium isolates. In this respect, efficient genomic DNA extraction methods from various plant matrixes should be screened. The PCR detection limit of fungalspecific DNA fragments from plant genomic DNA will be also determined.

\section{Acknowledgment}

This research was supported by a grant from the Agricultural R\&D Promotion Center (04601-20090004), and the Korea Research Foundation Grant, funded by the Korean Government (MOEHRD, Basic Research Promotion Fund; KRF-2006-521-F00005).

\section{References}

Baayen, R. P., O’Donnell, K., Bonants, P. J. M., Cigelnik, E., Kroon, L. P. N. M., Roebroeck, E. J. A. and Waalwijk, C. 2000. Gene genealogies and AFLP analyses in the Fusarium oxysporum complex identify monophyletic and non-mono- phyletic formae speciales causing wilt and rot diseases. Phytopathology 90:891-900.

Bogale, M., Wingfield, B. D., Wingfield, M. J. and Steenkamp, E. T. 2007. Species-specic primers for Fusarium redolens and a PCR-RFLP technique to distinguish among three clades of Fusarium oxysporum. FEMS Microbiol. Lett. 271:27-32

Chi, M. H, Park, S. Y. and Lee, Y. H. 2009. A quick and safe method for fungal DNA extraction. Plant Pathol. J. 25:108111.

Gerlach, W. and Nirenberg, H. I. 1982. The genus Fusarium-a pictoral atlas. Mitt Biol Bundesanst Land- Forstwirtsch, Berlin, Germany.

Geiser, D. M., Ivey, M. L. L., Hakiza, G., Juba, J. H. and Miller, S. A. 2005. Gibberella xylarioides (anamorph: F. xylarioides), a causative agent of coffee wilt disease in Africa, is a previously unrecognized member of the G. fujikuroi species complex. Mycologia 97:191-201.

Hawa, M. M., Salleh, B. and Latiffah, Z. 2010. Characterization and intraspecific variation of Fusarium semitectum (Berkeley and Ravenel) associated with red-fleshed dragon fruit (Hylocereus polyrhizus [Weber] Britton and Rose) in Malysia. African J. Biotechnol. 9:273-284.

Kim, H. K., Lee, T. and Yun, S. H. 2008. A putative pheromone signaling pathway is dispensable for self-fertility in the homothallic ascomycete Gibberella zeae. Fungal Genet. Biol. 45: 1188-1196.

Liu, Y. L., Whelen, S. and Hall, B. D. 1999. Phylogenetic relationships among ascomycetes: evidence from an RNA polymerase II subunit. Mol. Biol. Evol. 16:1799-1808.

Mehl, H. L. and Epstein, L. 2007. Identification of Fusarium solani f. sp. cucurbitae race 1 and race 2 with PCR and production of disease-free pumpkin seeds. Plant Dis. 91:12881292.

Mulè, G., Susca, A., Stea, G. and Moretti, A. 2004. A species-specific PCR assay based on the calmodulin partial gene for identification of Fusarium verticillioides, F. proliferatum and $F$. subglutinans. Eur. J. Plant Pathol. 110:495-502.

O’Donnell, K. and Cigelnik, E. 1997. Two divergent intragenomic rDNA ITS2 types within a monophyletic lineage of the fungus Fusarium are nonorthologous. Mol. Phylogenet. Evol. 7:103-116.

O’Donnell, K., Kistler, H. C., Cigelnik, E. and Ploetz, R. C. 1998. Multiple evolutionary origins of the fungus causing Panama disease of banana: Concordant evidence from nuclear and mitochondrial gene genealogies. Proc. Natl. Acad. Sci. USA 95:2044-2049.

Tamura, K., Dudley, J., Nei, M. and Kumar, S. 2007. MEGA4: Molecular Evolutionary Genetics Analysis (MEGA) software version 4.0. Mol. Biol. Evol. 24:1596-1599.

Thompson, J. D., Higgins, D. G. and Gibson, T. J. 1994. CLUSTALW: improving the sensitivity of progressive multiple sequence alignment through sequence weighting, positionspecific gap penalties and weight matrix choice. Nucleic Acids Res. 22:4673-4680. 